Open Access

\title{
The Video Journal and Visual Pedagogies: in the age of visual cultures
}

\author{
Michael A. Peters ${ }^{1}$ and E. Jayne White $2^{2^{*}}$
}

\author{
* Correspondence: \\ whiteej@waikato.ac.nz \\ ${ }^{2}$ Te Whiringa, Faculty of Education, \\ University of Waikato, Private Bag \\ 3105, Hamilton 3240, New Zealand \\ ${ }^{1}$ Wilf Malcolm Institute for Educational \\ Research, Faculty of Education, \\ University of Waikato, Private Bag \\ 3105, Hamilton 3240, New Zealand
}

Keywords: Visuality; Visual; Pedagogy; Open; Publishing

Michael Peters and Jayne White introduce their thinking behind the development of the journal at the inaugural conference of the Association for Visual Pedagogies in Zagreb, June, 2016. They set the scene and pohilosophical parameters for a broad and forwardlooking interpretation of visuality and the rise of visual studies by establishing an expanded route for the location of video Pedagogies in educational spaces. The video journal is introduced as a third generation form of scientific communication after the print-based journal and the digital online journal. The concept of the journal as the cornerstone of the scientific enterprise has evolved as new media technologies have become available. Industrial media known for its broadcast functionality of one to the many now is being replaced and remediated with video and mixed media increasingly with an accent on responsiveness and interactivity. In the second part of the presentation forms of visuality are explored and new visualization methodologies are discussed. An agenda is established for the potential and possibilities for Video Journal for Education and Pedagogy as a theoretical, philosophical, sociological, methodological and pedagogical site for future scholarship.

The video is available to download if requested from editorial@videoeducationjournal.com.

Acknowledgements

Thanks to Milan for capturing the footage and to Petar Jandric for his hospitality.

Received: 26 August 2016 Accepted: 26 September 2016

Published online: 21 October 2016
Submit your manuscript to a SpringerOpen ${ }^{\circ}$ journal and benefit from:

- Convenient online submission

Rigorous peer review

- Immediate publication on acceptance

- Open access: articles freely available online

- High visibility within the field

- Retaining the copyright to your article

Submit your next manuscript at $>$ springeropen.com 